\title{
Hungarian science confronts its past
}

\author{
Christopher Anderson
}

Despite resistance, there is a revolution in progress among Hungary's research community. The signs are promising that the legacy of Soviet-style inefficiency will give way to a brighter future.

\section{Budapest}

IN Hungary, perhaps the best-prepared of all the Eastern European countries to throw off 40 years of Soviet-style science, some shackles are proving hard to lose. While the country as a whole wrestles with the job of simultaneously reforming an economy, a political system, an industrial base and a national attitude, Hungarian scientists are just trying to get their Academy to relax its stranglehold on the country's research institutions.

As an internal revolution, it is a curious thing to watch. Three years after the country itself abandoned the last vestiges of Communism, the scientific establishment is turning out to be surprisingly resistant to change.

Most of the academy's members were installed long before the political reforms, and everyone knows which were appointed because they were members of the Communist Party. The academy controls its institutions largely as it did before, directing most of the research programmes with central committees of "old guard", who, the younger researchers complain, are still just as likely as they ever were to fund work on political grounds.

Nevertheless, there is a revolution going on, albeit a rather quiet one. There are no tanks in the street and no protests outside the academy, but throughout Hungary's research community there are demands for the reforms along the lines of those that took place in the streets of Budapest itself 3 years ago. "It's a typical transition period for Hungary", says Lajos Nyiri, a former Hungarian science attaché: "It's absolutely clear that it is changing, but it is not clear where." It is also not clear when it will be resolved. One of the constants in Hungarian science is the ability of the academy to mire reforms - especially threatening reforms - in bureaucracy.

"Everything there runs at a palaeozoic rate of change", says Lawrence Cohen, environment, science and technology attaché for the US embassy. Outside the academy, Hungary has embraced Western ways. In the mid-1980s it had private businesses, commercial banks and even the makings of a stock market.

Even while it was a member of the Soviet bloc and looked east for trade, its historical ties to Austria (Vienna is just a few hours up the Danube) left it with one foot in the European door. Hungarian NATURE · VOL 355 - 20 FEBRUARY 1992 industry also stayed close to international standards, although maintaining that productivity sometimes came at an economic cost to the country, which has the largest debt in Eastern Europe.

At the moment, however, Hungary is a troubled country. Its economy is a mess (inflation was 36 per cent last year), its people are, if anything, more dour than usual (it has the world's highest suicide rate; 4,235 Hungarians killed themselves in 1990), and its currency is still not stable enough to be convertible.

But it is also on its way up. Despite the collapse of the Soviet economy, Hunga-

\section{HUNGARIAN SCIENCE AT A GLANCE}

No. of full-time researchers 20,000

No. of academy research institutes

No. of universities

No. of specialized colleges

Total research/development funding $\$ 630 \mathrm{~m}$ Government funding*

$\$ 32 \mathrm{~cm}$

* Exchange rate 63 forint per dollar (1990 figures).

ry's traditional market, Hungary has the best trade balances in Eastern Europe and actually showed a trade surplus with the West last year. Goods - even Western goods - are plentiful and the only queues in Budapest are outside the Nike and Levis stores. Budapest is also home to Europe's most successful MacDonalds. Unemployment, despite the elimination of thousands of state-supported jobs, is still very low - less than 3 per cent. Wages are even lower, however, so many Hungarians have to do two jobs to keep their heads above water. The only place to get a live basil plant in Budapest is from a roadside stand operated by a agricultural engineer from one of the Academy of Sciences laboratories. She leaves her first job at about 4:00 every afternoon so she can get to her stand in time to meet the evening shopping rush. It is almost impossible to find a government office still functioning after $4: 30$.

Hungarian science is one of the bright spots in the country's future. It is the best in Eastern Europe (see graph on page 670 ) and it is strong in the applied sciences, an indirect result of declining government support of basic science over the past decade, which forced many of the university research institutions to find support from industry. Although Hungarian industry cannot support much science in its current state, the experience of working in applied fields should improve Hungarian scientists' chances of finding work from Europe and the United States.

The language barrier, of course, remains a problem. According to academy statistics, only about a quarter of Hungarian researchers have passed competency exams in English, about the same number that passed Russian. After years of reviewing research proposals in-house, the Academy of Sciences and the government research fund (OTKA) are now starting to send them out for review by researchers in Austria and Finland to avoid longstanding charges of favouritism and bias in academy review. This means, of course, that the proposals must be written in English, something that may separate the old from the new guard. "The new generation and the ambitious speak English", says Géza Bittsànszky, head of the government's secretariat for science policy. "This may help trim the community."

Slimming the overpopulated and inefficient state-supported research machine is an oft-repeated goal, although there is little, short of underfunding, that the government is doing about it. Although everyone agrees that many of the academy research institutes were of poor quality, there has until recently been little in the way of impartial analysis to point out the culprits. A move to competitive grants and a real peer-review system, announced last year (see Nature 352, 745; 1991), will help. So will a parallel initiative to bring the universities to the Wesıarn model. The Athenaeum Initiative, one of the proposals now being considered, would allow universities to offer Western-style PhDs, a substantial departure from the current system in which the Hungarian Academy of Sciences decides who gets the advanced degrees that are necessary for tenured positions.

It is rather un-Hungarian for them to say so, but scientists admit that their current situation could in fact be a good deal worse. It could be Russia - indeed, the Soviet-style Academy of Sciences, with its ageing research institutes and academicians is for many researchers a reminder of just what was wrong with the bad old days. 